\section{Political Scientists, Reporters Named Congressional Fellows}

The American Political Science Association has announced the winners in the national competition for the 1990-91 Congressional Fellowship Program. Fellows come to Washington in November for a one-month orientation session followed by nine months of full-time work as legislative aides in congressional offices. are:

The new Congressional Fellows

Joseph Beck, State Government Reporter, Washington State Journal, Madison, Wisconsin

Nick Beres, General Assignment Reporter, KTVL-TV, Medford, Oregon

Sophia Byrd, Editorial Writer, The Herald, Everett, Washington

Robert Dilger, Associate Professor, Department of Political Science, University of Redlands

Daniel Franklin, Assistant Professor, Department of Political Science, Colgate University

Marlene K. Harris, Reporter, WOSU Radio, Columbus, Ohio

Mark Peterson, Henry LaBarre

Jayne Associate Professor of Government, Harvard University

Lyn Ragsdale, Associate Professor, Department of Political Science, University of Arizona

Sponsored by the Association since 1953, the purpose of the Congressional Fellowship Program is to give outstanding political scientists, journalists, medical faculty and federal agency executives an opportunity to acquire a rich understanding of the national legislative process.

The Selection Committee was com- posed of Ronald D. Elving, Congressional Quarterly, Inc.; Albert R. Hunt, The Wall Street Journal; Carol Matlack, National Journal; Roger H. Davidson, University of Maryland; Christopher J. Deering, George Washington University and Director of Academic Planning and Development, Congressional Fellowship Program; Candice J. Nelson, former Visiting Fellow, The Brookings Institution; and James A. Thurber, The American University.

The 1,352 alumni of the program include university presidents, deans and professors; newspaper and magazine publishers, editors and reporters; high-ranking executives in the federal bureaucracy; and congressmen and congressional staff aides.

Other participants in the 1990-91 program will be announced later in the year.

\section{Nick Beres Named Joan Shorenstein Barone Congressional Fellow}

Nick Beres, reporter for CBS affiliate KTVL-TV of Medford, Oregon, has been named the 1990-91 Joan Shorenstein Barone Congressional Fellow by the American Political Science Association. This Fellowship is awarded to an outstanding broadcast journalist through a national competition each year.

As the Joan Shorenstein Barone Congressional Fellow, Mr. Beres will participate in APSA's Congressional Fellowship Program which includes other journalists, political scientists, health policy professionals and federal government executives who have been selected through a rigorous national competition. The Fellows spend 10 months working closely

\title{
Directory of Department Chairpersons
}

Each fall APSA sends a postcard to department chairs requesting them to update their department's address, phone number, and chair name. This information is used to update our mailing list and is published in an annual Directory of Department Chairpersons. Typically, we receive a $50 \%$ response rate to our mailing. In order to insure accuracy in the Directory, we encourage all departments to update their listings. with Members of Congress and congressional committees as legislative assistants and attending weekly seminars and lectures by experts on the political process.

Before joining KTVL-TV, Mr. Beres was an on-air correspondent for WRCB-TV, NBC affiliate in Chattanooga, Tennessee. $\mathrm{He}$ is a graduate of the University of Oregon and has a Master of Science in Journalism from the Medil School of Journalism, Northwestern University.

The Joan Shorenstein Barone Congressional Fellowship commemorates Joan Shorenstein Barone and the standards she set for accurate, thorough, and dignified reporting of current events, first as a researcher at The Washington Post and subsequently as a producer at CBS News. Joan Shorenstein Barone was a member of the Washington staff of the CBS Evening News at the time of her death in 1985.

Funding for the Joan Shorenstein Barone Congressional Fellowship is generously provided by her parents, Walter and Phyllis Shorenstein, and family.

\section{Lyn Ragsdale Named William A. Steiger Congressional Fellow}

Lyn Ragsdale, Associate Professor, Department of Political Science, University of Arizona, has been named the second William A. Steiger Congressional Fellow by the American Political Science Association. The Fellowship is awarded each year to an outstanding political scientist or journalist through a national competition.

As the William A. Steiger Congressional Fellow, Dr. Ragsdale will participate in APSA's Congressional Fellowship Program which includes other political scientists, journalists, health policy professionals and federal government executives who have been selected through a rigorous national competition. The Fellows spend 10 months working closely with Members of Congress and congressional committees as legislative assistants and attending weekly seminars and lectures by experts on the political process. 